\title{
Investigating the Relationship between Physical Infrastructure and Economic Growth in the Middle East and North Africa
}

\author{
Waleed Mohamed Youssef \\ Assistant Professor of Economics \\ Faculty of Business - Ain Shams University
}

\begin{abstract}
This paper investigates the impact of physical infrastructure development on economic growth in MENA region. It adopts generalized method of moments with system estimators to estimate an endogenous growth model during 2000-2016 for a sample of 30 developing or emerging countries including nine MENA countries. It utilizes the generalized method of moments (GMM) to account for heterogeneity and endogeneity in the specified model. This growth model is augmented with a synthetic infrastructure quantity index developed using the principal components analysis (PCA) for two infrastructure sectors, which are telecommunications and energy. The results reveal that infrastructure quantity has contributed positively to economic growth for the whole sample of countries as well as MENA countries, and the specification tests validates the specified model.

Keywords: Physical infrastructure, Infrastructure quantity, Telecommunications, Energy, Economic Growth, Middle East and North Africa, Heterogeneity, Endogeneity, Generalized Method of Moments, Principal Component Analysis

Email: waleed.youssef@ bus.asu.edu.eg
\end{abstract}




\section{Introduction}

Physical infrastructure plays a crucial role in promoting and sustaining economic growth both directly as an input in the production process, and indirectly by raising the productivity of other inputs to production. Physical infrastructure includes roads, telecommunications, energy, water and sanitation, etc. According to the theory, physical infrastructure development contributes positively to economic growth, whereas the magnitude of such contribution is debatable among empirical studies. Although, the majority of empirical studies have found that infrastructure has contributed positively to economic growth in most countries, the magnitude of such contribution has differed largely due to differences in data, infrastructure measures, and econometric estimation techniques.

In this regard, synthetic infrastructure indices can be adopted to account for both quantity and quality of physical infrastructure instead of depending on monetary measures of physical infrastructure. Meanwhile, the econometric techniques have been developed to face econometric challenges such as endogeneity resulting from the reverse causality between infrastructure development and economic growth, as well as other econometric challenges.

Among the World regions, Middle East and North Africa $(\mathrm{MENA})^{1}$ region has promising growth potentials given its resource base. Nevertheless, MENA has a volatile growth record due to its high dependence on oil with its fluctuating prices, which largely affect both oil-exporting and non-oil-exporting countries.

In this way, it is apparent that MENA countries should shift to a new development model with more economic diversification

1 Middle East and North Africa is defined to include Algeria, Bahrain, Djibouti, Egypt, Iran, Iraq, Israel, Jordan, Kuwait, Lebanon, Libya, Morocco, Oman, Qatar, Saudi Arabia, Syria, Tunisia, United Arab Emirates, West Bank and Gaza, and Yemen. 
and greater role for the private sector. Nevertheless, the success of this new model will require some factors, and among these factors is the infrastructure development. Meanwhile, infrastructure development can be considered as a potential source for sustaining economic growth in the region, given that the region is still lagging behind developed regions in terms of both the quantity and quality of physical infrastructure.

Thus, this paper is trying to investigate whether physical infrastructure contributes positively to economic growth in MENA. The paper adopts system-GMM estimators to estimate an endogenous growth model that is augmented with a synthetic infrastructure quantity index for telecommunications and energy. The paper is trying to fill the research gap resulting from the limited number of empirical studies that estimated the impact of physical infrastructure on economic growth in MENA, while using a different econometric technique than those used in other MENA studies.

The rest of the paper is organized as follows. The next section reviews the theoretical empirical literature on the relationship between infrastructure development and economic growth. Section three analyzes the MENA growth record as well infrastructure development compared to other World regions. Section four details the methodology adopted in this paper, while section five shows the main results of econometric estimation while accounting for MENA countries using an interaction term Finally, section six concludes with the main policy implications of the paper.

\section{Literature Review}

In economics, infrastructure could be defined in terms of its characteristics. In this way, infrastructure is defined as capital that provides public services, and hence, it is sometimes referred to as social overhead capital. Infrastructure can be divided into two forms as physical infrastructure and social infrastructure. 
On the one hand, physical infrastructure is the infrastructure that promotes economic activity, such as roads, highways, railroads, airports, sea ports, electricity, telecommunications, water supply and sanitation. On the other hand, is the infrastructure that promotes the health, education and cultural standards of the population. However, physical and social infrastructure do overlap. Sanitation, for example, would have both an economic and health impact and can be considered as both economic and social infrastructure.

In this regard, the impact of infrastructure on economic growth has been studied and analyzed in economic theory and empirical studies, while focusing on physical infrastructure. The following sub-sections will address the impact of physical infrastructure on economic growth both in theory and empirical studies.

\subsection{Physical Infrastructure and Growth in Theory}

Growth theories try to investigate the reasons behind economic growth answering the important questions of how and why countries differ in their growth levels. Three main strands of economic thought have dominated the economics of growth.

The first strand is the Capital Fundamentalist View that stressed the importance of capital accumulation for the growth process and was dominated by the classical and Keynesian economists. The second strand appeared in the 1950s and was represented by the neoclassical growth theory that viewed economic growth as caused by exogenous factors (determined outside the growth model), among which is technical progress. Recently, a new school of thought in economic growth has emerged in the 1980s; it was the new or endogenous growth theory, which viewed economic growth as an endogenous process resulting from factors inside the economy (Todaro and Smith, 2011).

Although the three strands of growth theory differ in their analysis of the sources of growth mainly in the long run, all strands stress the importance of physical capital accumulation, particularly physical capital. Physical capital plays a crucial role in promoting and sustaining economic growth both directly as an input in the production process, and indirectly by raising the 
productivity of other inputs to production as suggested by growth theory.

\subsection{Empirical Literature on Physical Infrastructure and Growth}

Although the economic theory suggests that physical infrastructure development contributes positively to economic growth, the magnitude and limits for such positive contribution was largely controversial in empirical studies. Such studies have started in the late 1980s with the seminal paper by Aschauer in 1989. In this context, empirical studies can be classified according to how physical infrastructure is accounted for.

\subsubsection{Monetary Measures of Physical Infrastructure}

The early studies accounted for physical infrastructure using monetary measures, mainly public capital spending. Aschauer (1989) estimated the impact of public capital stock (measured in monetary values) on the U.S. productivity, and found that there is a large positive impact on the U.S productivity specifically for the non-military structures such as highways, roads, and water systems. However, the implausibly large elasticity of output productivity growth to infrastructure suggests that there is spurious regression.

Barro (1990) also investigated the relationship between public capital spending and economic growth. Barro argued that there is an optimal level for public capital spending above which the contribution of public capital spending to growth will be negative, and this rule was then known as 'Barro Rule .'

Devarajan et al. (1996) studied the impact of public expenditure on economic growth for a panel of developing countries using fixed and random effects analyses, while differentiating between current and capital expenditures. They found that current expenditures have a positive impact, whereas capital expenditures (infrastructure expenditures) have a significant negative impact on economic growth, indicating that developing 
countries misallocated public expenditures in favor of capital expenditures at the expense of current expenditures.

The results of such early studies were apparently different and doubtful for some reasons. Among these reasons are the nonstationarity of time-series data leading to spurious regression (Jorgenson, 1991), the endogeneity problem due to reverse causality between output and infrastructure (Cashin, 1995), the measurement errors in public capital proxies (Baltagi and Pinnoi, 1995), and the adoption of monetary measures for infrastructure (Calderón and Servén, 2014).

\subsubsection{Quantity and Quality Measures of Physical Infrastructure}

Another strand of empirical studies has emerged since the late 1990s with the aim of avoiding the limitations of the early studies. In this sense, these studies included physical infrastructure using quantity and/or quality measures and adopted advanced statistical techniques for panel-data analysis. One of the leading studies was Sanchez-Robles (1998).

Sanchez-Robles (1998) explored the relationship between infrastructure development and economic growth, while accounting for infrastructure in two different ways. On the one hand, infrastructure was accounted for by expenditure on infrastructure as a percentage of GDP. On the other hand, a synthetic index of physical infrastructure stock was adopted. The weights used in developing this index were derived from principal component analysis (PCA) to avoid multicollinearity between different infrastructure sectors.

The results reported by Sanchez-Robles (1998) argued that expenditure on infrastructure had a negative impact on economic growth, whereas the regressions that adopted an infrastructure quantity index showed a significant positive impact for infrastructure on economic growth. Therefore, this study implies that the results of empirical studies might differ depending on how infrastructure was accounted for. 
Following the methodology used by Sanchez-Robles (1998), some studies have included physical infrastructure in the growth model using quantity and/or quality indices based on PCA for different infrastructure sectors, mainly electricity, telecommunications, and roads. However, such studies have adopted an advanced econometric technique for panel-data analysis that is the generalized method of moments (GMM), so that to face the endogeneity problem. Among these studies were Calderón and Servén $(2004,2010)$.

Calderón and Servén (2004) used a variety of GMM estimators to investigate the impact of infrastructure on economic growth for more than 100 countries during 1960-2000, while adopting both disaggregated and synthetic indices for infrastructure. They found that the infrastructure index has positively affected economic growth .

Calderón and Servén (2010) adopted system-GMM estimators for 136 developing countries during 1960-2005 with nonoverlapping 5-year averages, and argued that both infrastructure quantity and quality have contributed positively to economic growth. Such results were also proved for the Latin American countries after introducing an interaction term with the Latin American dummy variable.

In this context, some studies have followed the same methodology while focusing on developing countries. Chakamera and Alagidede (2016) used difference-GMM estimators for 43 Sub-Saharan African countries during 20002014 and reported a positive impact for both infrastructure quantity and quality indices on economic growth .

Kodongo and Ojah (2016) adopted system-GMM estimators for 45 Sub-Saharan African countries during 2000-2011. They argued that infrastructure spending has a significant positive effect on economic growth compared to infrastructure stock, especially for lesser-developed countries.

Yilmaz and Çetin (2017) found that infrastructure quantity has contributed positively to economic growth in 29 developing 

estimators, given that physical infrastructure has been included using a synthetic quantity index.

\subsubsection{MENA Studies}

Although infrastructure development is crucial for sustaining economic growth in MENA, the studies that focused on the impact of physical infrastructure on economic growth in this region are rare. Among these studies are Nabli and VeganzonesVaroudakis (2007) and Um et al.(2009) .

Nabli and Veganzones-Varoudakis (2007) used fixed-effect panel analysis to estimate an endogenous growth model with physical infrastructure stock for a panel of 44 developing countries including seven MENA countries (Djibouti, Egypt, Iran, Jordan, Morocco, Syria, and Tunisia) during 1970-1992. They found that physical infrastructure stock has a significant positive impact on economic growth in MENA.

Um et al. (2009) applied growth accounting regression to conclude that only electricity generation had a significant positive impact on total factor productivity (TFP) growth in a panel of 112 countries including eight MENA countries (Algeria, Egypt, Iran, Israel, Jordan, Morocco, Syria, and Tunisia) during 1960-2005. Meanwhile, they adopted crosscountry growth regression and found that on average each of electricity generation and telecommunications has contributed positively to economic growth in a panel of 102 developing or emerging countries including 20 MENA countries during 19712006.

This paper will differ from the previous MENA studies on infrastructure and growth both in the methodology utilized and the set of countries included in our sample as it will be shown in the fourth section of this paper. 


\section{MENA Growth Record and Infrastructure Development}

MENA countries are characterized by being diverse in terms of size, geography, level of income, natural resource endowments, economic structure, and economic policies and institutions. However, the region still shares many economic features.

Among these economic features are largely similar production bases that depend mainly on primary products at the expense of manufacturing, lack of water resources, lack of environmental sustainability, and poor institutions and governance. In this context, the dependence on oil for rapid economic and social development is the most common feature between both oilexporting and non-oil exporting countries (Duncan and Denaux, 2013).

On the one hand, the oil-exporting countries depend mainly on revenues from oil exports to finance their development plans, since such revenues represent $70-85 \%$ of public revenues in some MENA countries like Gulf countries. On the other hand, worker remittances and aid flows from oil-exporting countries represent a major source of revenues for the non-oil- exporting countries (Nabli, 2007). Thus, MENA's growth record has been largely affected by the changes in World oil prices since the 1970s.

In this regard, MENA region has a volatile economic growth record that is largely dependent on World oil prices and its fluctuations. Such volatile growth record is represented in figure (1), where growth rates rise in the periods of rising oil prices and fall at the periods of declining oil prices. This pattern was apparent in the 1970s that witnessed an average real GDP growth of $8.5 \%$ because of the surge in World oil prices after the 1973 war from US\$ $2.7 /$ barrel to US\$ $11 /$ barrel in $1974^{2}$.

${ }^{2}$ Based on tables (A.1) and (A.2) in appendix A.

Scientific Journal for Economic\& Commerce 


\section{Figure (1)}

\section{Real GDP Growth versus Change in OPEC Crude Oil Price (\%)}

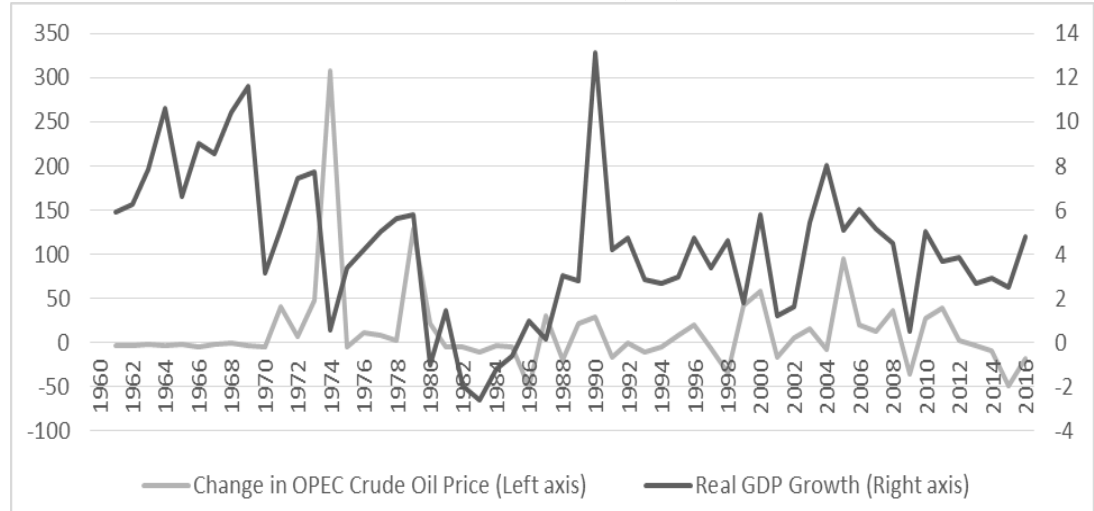

Source: World Bank, World Development Indicators

Conversely, the 1980s witnessed a clear decline in real GDP growth, which averaged just $0.11 \%$ with the fall in World oil prices in the mid-1980s. For instance, the OPEC crude oil price has decreased from US $\$ 35.52 / \mathrm{barrel}$ in 1980 to US\$ $13.53 /$ barrel representing a decline of about $62 \%$ in World oil prices.

Such strong correlation between economic growth and World oil prices in MENA region stems from the high dependence of the region's countries on oil revenues. Figure (2) shows that oil rents as a percentage of GDP in MENA largely exceed such rents in other World regions, particularly the developed regions such as North America and Europe and Central Asia. 
Oil Rents (\% of GDP)

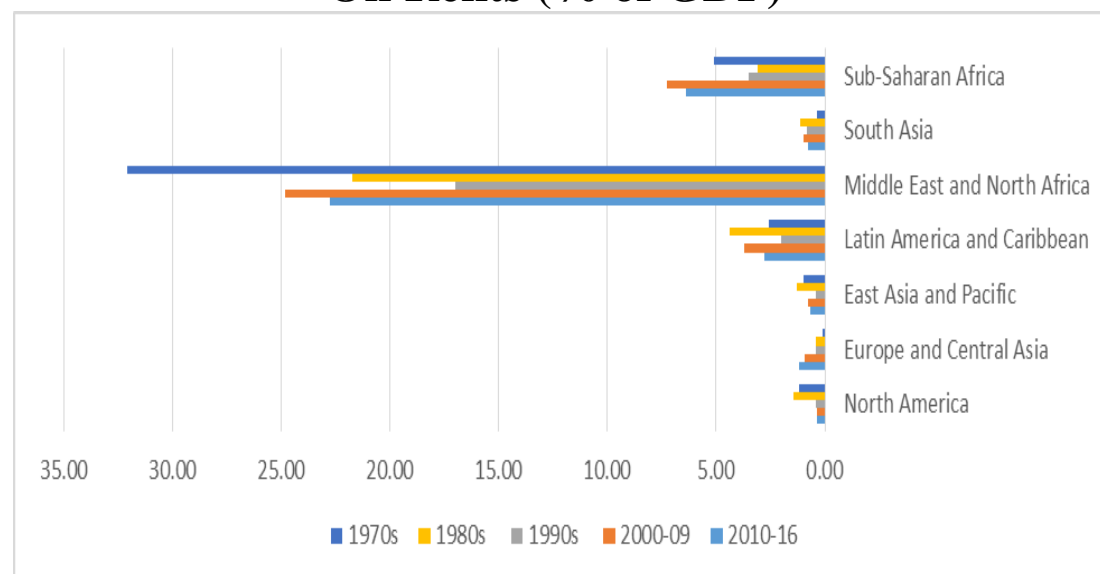

Source: World Bank, World Development Indicators

Meanwhile, MENA has not been able to sustain the high economic growth rates achieved in the 1970s, and the region suffered from a declining growth trend since the 1990s compared to developing regions like South Asia and SubSaharan Africa that witnessed a rising growth trend since then, as illustrated by figure (3).

Such fluctuating growth record has caused a mounting unemployment problem in MENA region, and especially the oilimporting countries. This was due to the insufficient job creation and the expanding labor force supply in these countries. 


\section{Figure (3)}

Average Real GDP Growth (\%)

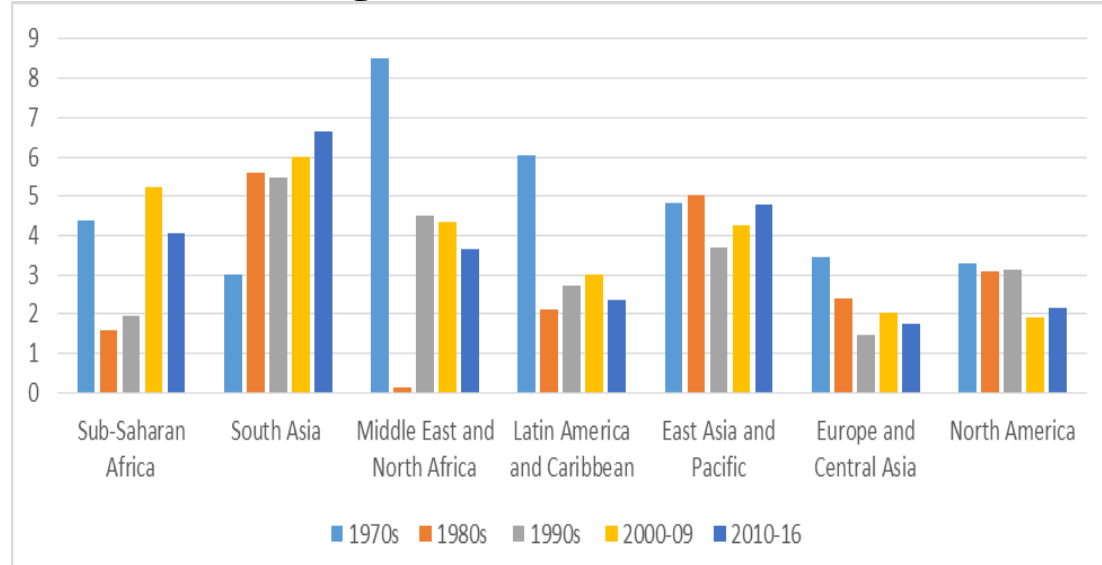

Source: World Bank, World Development Indicators

In this sense, it appears that this old development model should be changed and a transition towards a new model is required. This new model should aim at diversifying the region's economic structure through giving a greater role for the private sector and opening the economy with increased manufactured exports (Nabli, 2007).

Nevertheless, the success of this new model will require some essential factors like better governance, higher-quality education, improved healthcare, and well-developed infrastructure. Here, infrastructure development should be at the center of such new development model. Particularly, physical infrastructure is required for supporting private investment and facilitating MENA's integration into the World economy.

In this context, although MENA countries have achieved real progress in terms of physical infrastructure provision, they are still lagging behind North America, Europe and Central Asia, and East Asia and Pacific as illustrated by the following figures. Figure (4) shows that MENA has improved in terms of the percentage of population with access to electricity, which is 
leveled with that of Latin America and East Asia and Pacific, and not so much far from that of developed regions .

Figure (4)

Access to Electricity (\% of Population)

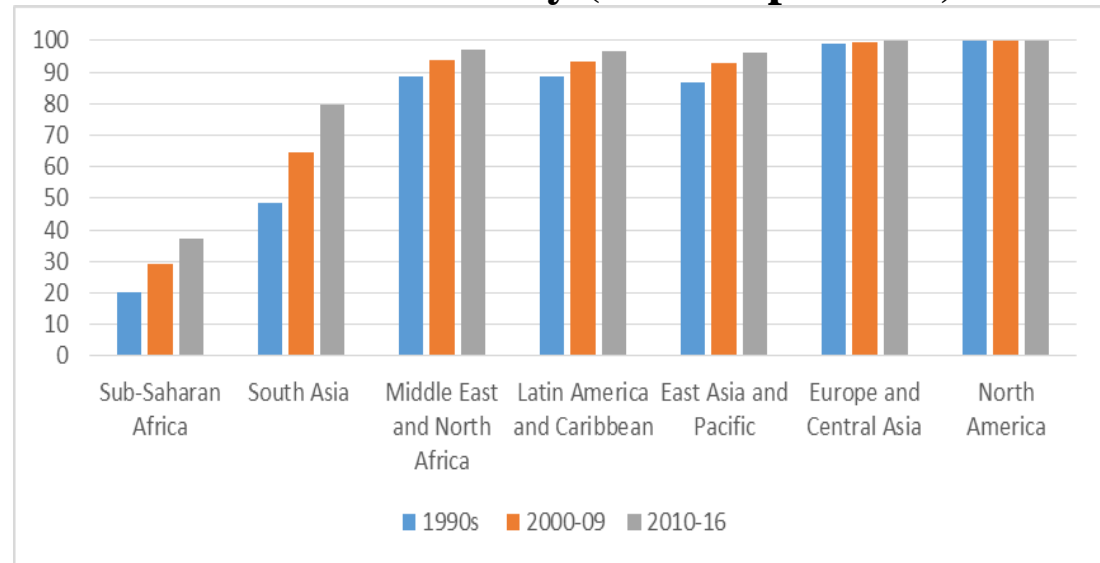

Source: World Bank, World Development Indicators

However, MENA is still largely falling behind North America as well as Europe and Central Asia in terms of electric power consumption as shown in figure (5), although MENA has passed Latin America since the 2000s.

Figure (5)

\section{Electric Power Consumption (kWh per Capita)}

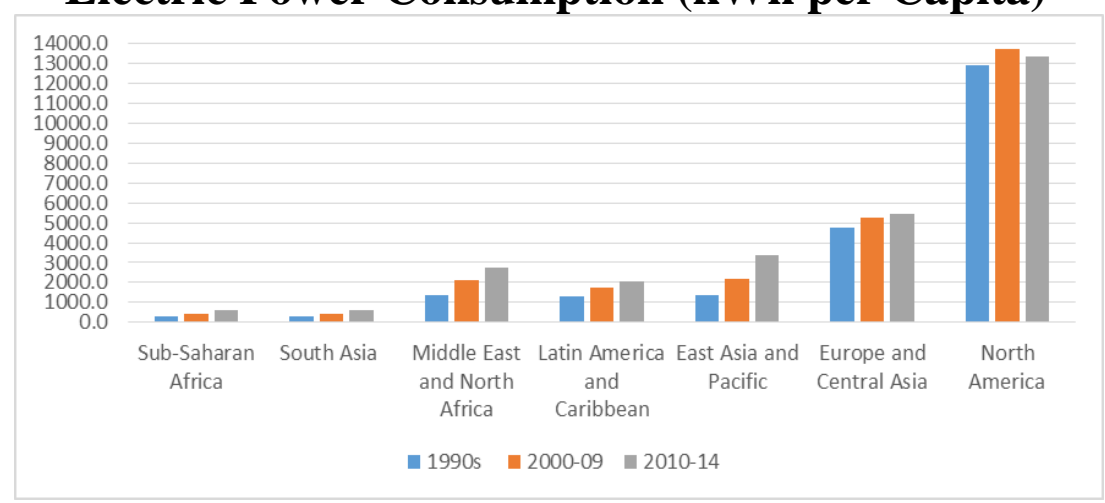

Source: World Bank, World Development Indicators 
In addition, MENA has achieved some improvement in fixed telephone subscriptions since the 2000s, but the region is still facing a gap with developed regions as illustrated by figure (6).

Figure (6)

\section{Fixed Telephone Subscriptions (Per 100 People)}

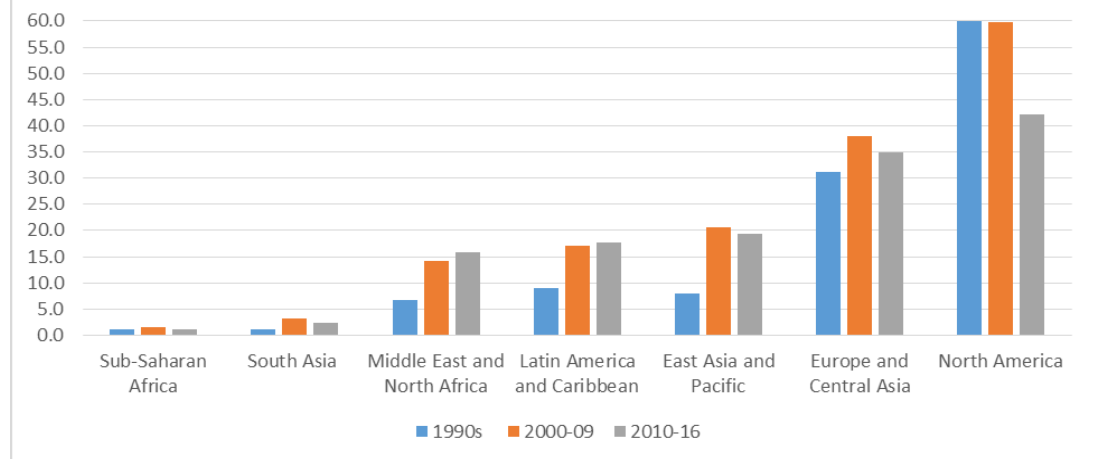

Source: World Bank, World Development Indicators

Based on the above analysis, it is obvious that MENA is still facing a gap in infrastructure provision with developed regions, and hence, physical infrastructure provision might be a potential source of sustainable economic growth in the MENA region given that the MENA growth record is largely volatile with the fluctuating oil prices.

Nevertheless, such conclusion depends on the hypothesis that physical infrastructure contributes positively to MENA's economic growth and this paper is trying to investigate such hypothesis.

\section{Methodology}

Based on the literature review, it appears that the empirical investigation of the impact of physical infrastructure on economic growth faces three main challenges. Firstly, the difficulty of measuring infrastructure and accounting for its quantity and quality. Secondly, the endogeneity problem between the different variables, particularly the reverse causality between output and infrastructure. Finally, the heterogeneity 
problem that results from the unobserved specific country effects in panel-data studies.

That is why this paper will follow a methodology that is trying to overcome the above-mentioned challenges. In this regard, the paper is trying to fill the research gap that is due to the limited number of empirical studies that estimated the impact of physical infrastructure on economic growth in MENA. Meanwhile, the originality of this paper stems from using a methodology that is different from that used on other MENA studies, as shown in this section.

\subsection{Data}

This paper estimates the impact of physical infrastructure on economic growth for a panel of 30 developing or emerging countries $^{3}$ during 2000-2016, while focusing on two infrastructure sectors that are telecommunications and Energy. The panel includes nine MENA countries, which are Algeria, Bahrain, Egypt, Iran, Jordan, Morocco, Saudi Arabia, Tunisia, and Turkey.

In this context, the number of telephone lines (fixed and mobile cellular) per 100 people was used as a proxy for the stock of telecommunications, whereas the stock of energy was measured by the electric power generation capacity in kilowatt-hour $(\mathrm{kWh})$ per 100 people. The source for data of both sectors is the World Development indicators by the World Bank.

Such quantity indicators for both sectors were then grouped together to formulate a synthetic infrastructure quantity index for different countries using the principal component analysis (PCA) following Sanchez-Robles (1998), Calderón and Servén (2004, 2010), Chakamera and Alagidede (2016), and Yilmaz and Çetin (2017). In this way, this paper differs from other MENA studies that included infrastructure using multiple indicators rather than a single synthetic index as it is the case in

${ }^{3}$ The whole set of countries is listed in appendix B. 
this paper. Nevertheless, the paper will focus only infrastructure quantity due to data limitations in infrastructure quality indicators for many countries.

PCA is one of the oldest multivariate analysis techniques that aims at transforming a large number of correlated variables into a limited number of variables known as the principal components. Such principal components are uncorrelated and the first principal components usually keep the largest variation in all variables (Yilmaz and Çetin, 2017). That is, the first principal components explain most of the variation in the variables, and hence, such principal components can then be included in regression estimation to represent all variables while reducing the dimensionality and multicollinearity problems.

PCA uses ordinary correlations between all variables to calculate eigenvalues and eigenvectors for the principal components. The eigenvectors for the components with the highest explained variation can then be used as weights to formulate a synthetic index that involves all variables.

Since infrastructure indicators are characterized by multidimensionality as well as multicollinearity where the development of each infrastructure sector is largely dependent on that of other sectors, we can use PCA to generate a synthetic infrastructure index. The eigenvalues for the principal components of both infrastructure sectors in this study are represented in table (1). 


\section{Table (1)}

Eigenvalues for Infrastructure Sectors

\begin{tabular}{|c|c|c|c|}
\hline $\begin{array}{c}\text { Principal } \\
\text { Components }\end{array}$ & Value & $\begin{array}{c}\text { Proportion } \\
\text { Explained }\end{array}$ & $\begin{array}{c}\text { Cumulative } \\
\text { Proportion }\end{array}$ \\
\hline PC1 & 1.378 & 0.689 & 0.689 \\
\hline PC2 & 0.622 & 0.311 & 1 \\
\hline
\end{tabular}

Source: Calculated by the author using EViews 9

According to table (1), the eigenvalue for the first principal component of telecommunications and energy included in this study is 1.378 (greater than 1) and explains about $69 \%$ of the variation in both variables, and hence, this first principal component can be included in regression estimation .

We can then generate a synthetic quantity infrastructure index for each country in each year using the scores derived from the eigenvectors computed by EViews 9, given that the values of both infrastructure sectors are expressed in $\operatorname{logs}$ and standardized by subtracting its mean and dividing by its standard deviation. The equation for the synthetic index is:

$$
\begin{aligned}
& I_{\text {INST }}, t \\
& =0.707\left(\frac{\text { Total telephone lines }}{100}\right) \\
& +0.707\left(\frac{\text { Electric power generation }}{100}\right)
\end{aligned}
$$

According to equation (1), the scores are calculated with equal weights for both sectors (0.707) based on the results of PCA. This synthetic index $\left(\operatorname{INFST}_{i, t}\right)$ will be included as a variable in the regression estimation of the specified model.

\subsection{Model Specification}

The specified model is an endogenous growth model that is follows Barro (1991) with the aim of investigating the impact of physical infrastructure development on economic growth in MENA, while taking into account a set of control variables. The 
model takes the following form given that i represents country dimension and $t$ denotes time dimension:

$y_{i, t}-y_{i, t-1}=\beta_{0} y_{i, t-1}+\beta_{1} I N F S T_{i, t}+\beta_{2} X_{i, t}+\mu_{i}$

$$
+\epsilon_{i, t}
$$

In the above equation, $y_{i, t}$ is the log of real GDP per capita, whereas $y_{i, t}-y_{i, t-1}$ is real GDP per capita growth which is the dependent variable. It represents a dynamic panel model since the lagged per capita GDP growth $\left(y_{i, t-1}\right)$ is included as a regressor in the right hand-side of the equation to test for the transitional convergence hypothesis. This hypothesis claims that poor countries grow faster than rich ones, since poor countries are relatively far from their steady-state growth rate.

$I_{N F S T}$ i,t is the synthetic infrastructure index of telecommunications and energy generated by PCA as shown above. $X_{i, t}$ includes a set of control variables. The control variables involve a set of determinants that are considered among the most important factors that affect economic growth according to growth literature. The definition and sources of such control variables are detailed in table (2). $\mu_{i}$ represents the unobserved country-specific effects, while $\varepsilon_{i, t}$ is the idiosyncratic error term. 


\section{Table (2)}

\section{Definition and Sources of Control Variables}

\begin{tabular}{|c|c|c|}
\hline Variable & Definition & Source \\
\hline Education & $\begin{array}{l}\text { Education index in human development } \\
\text { index (HDI). It ranges from zero to } 1 \\
\text { indicating better education as it } \\
\text { approaches } 1 \text {. }\end{array}$ & $\begin{array}{l}\text { United Nations } \\
\text { Development } \\
\text { Program } \\
\text { (UNDP) }\end{array}$ \\
\hline $\begin{array}{c}\text { Trade } \\
\text { Openness }\end{array}$ & Trade as a $\%$ of GDP (in logs) & $\begin{array}{l}\text { World } \\
\text { Development } \\
\text { Indicators } \\
\end{array}$ \\
\hline Inflation & $\begin{array}{l}\text { Annual \% using consumer price index } \\
\qquad(\mathrm{CPI})\end{array}$ & $\begin{array}{l}\text { World } \\
\text { Development } \\
\text { Indicators }\end{array}$ \\
\hline Variable & Definition & Source \\
\hline $\begin{array}{c}\text { Financial } \\
\text { Development }\end{array}$ & $\begin{array}{c}\text { Domestic credit to private sector as a \% } \\
\text { of GDP (in logs) }\end{array}$ & $\begin{array}{l}\text { World } \\
\text { Development } \\
\text { Indicators }\end{array}$ \\
\hline $\begin{array}{l}\text { Government } \\
\text { Size }\end{array}$ & $\begin{array}{l}\text { General government final consumption } \\
\text { expenditures as a \% of GDP (in logs) }\end{array}$ & $\begin{array}{l}\text { World } \\
\text { Development } \\
\text { Indicators } \\
\end{array}$ \\
\hline $\begin{array}{l}\text { Institutional } \\
\text { Quality }\end{array}$ & $\begin{array}{l}\text { ICRG political risk index. Its score } \\
\text { ranges from zero to } 100 \text { and higher } \\
\text { scores indicate more political stability } \\
\text { (in logs). }{ }^{4}\end{array}$ & $\begin{array}{c}\text { International } \\
\text { Country Risk } \\
\text { Guide (ICRG) } \\
\text { by the PRS } \\
\text { Group }\end{array}$ \\
\hline
\end{tabular}

${ }^{4}$ ICRG political risk index is adopted as a proxy for institutional quality, since it is calculated using 12 components that are largely related to a country's institutional quality. These components include government stability, socioeconomic conditions, investment profile, internal conflict, external conflict, corruption, military in politics, religious tensions, law and order, ethnic tensions, democratic accountability, and bureaucracy quality. 


\subsection{Econometric Technique}

Since, the estimated model is a dynamic-panel data model as it includes a lagged dependent variable $\left(y_{i, t-1}\right)$ among the explanatory variables, the estimation of the model using ordinary least squares (OLS) will face some econometric challenges that will violate the classical linear assumptions for OLS estimation. Among these challenges are heterogeneity and endogeneity (Wooldridge, 2013).

On the one hand, heterogeneity stems from estimating the model for different countries with various time-invariant characteristics represented by the unobserved country-specific effects $\left(\mu_{i}\right)$. On the other hand, endogeneity results from the correlation between explanatory variables and the unobserved country-specific effects where $\operatorname{cov}\left(X_{i, t}, \mu_{i}\right) \neq 0$ which implies that explanatory variables are predetermined and not strictly exogenous, as well as the correlation between the lagged dependent variable and the idiosyncratic error term implying that $\operatorname{cov}\left(y_{i, t-1}, \varepsilon_{i, t}\right) \neq 0$ (Alimi, 2015).

Such endogeneity problem is apparent in the specified model as physical infrastructure development might be correlated to economic growth, and causality might run the other way too as economic growth might be correlated to physical infrastructure development, indicating that there is reverse causality.

Although, first differencing (FD) of the above model is a possible solution for heterogeneity, as it will rule out the unobserved country-specific effects, first differencing might largely reduce the variation in explanatory variables resulting in a larger standard error for coefficients, and thus, a lower $\mathrm{t}$ statistic and probably statistically insignificant variables. Furthermore, FD will not reduce the inconsistency of estimators even with large time periods if the lagged dependent variable is included in the model .

Here, fixed effects (FE) estimation can be a better solution for heterogeneity, particularly if the explanatory variables are not 
strictly exogenous. However, FE is largely sensitive to serial correlation, nonnormality, and heteroskedasticity compared to first differencing. Meanwhile, FE will not be able to deal with endogeneity. An alternative method that can deal with endogeneity is instrumental variables (IVs) estimation.

Such IVs should satisfy two main conditions to deal with endogeneity. Firstly, an instrumental variable should be correlated to explanatory variables, which is known as instrumental relevance. Secondly, an instrumental variable should not be correlated to the error term, which is known as instrument exogeneity. Nevertheless, IV estimator can have a large bias in small samples and we can face the problem of weak instruments if explanatory variables and IVs are weakly correlated (Wooldridge, 2013).

Accordingly, Arellano and Bond (1991) used an IV method to deal with endogeneity while estimating dynamic-panel data models with predetermined and not strictly exogenous variables. Such IV method is based on moment conditions, and thus it is known as the generalized method of moments (GMM).

Arellano and Bond (1991) proposed a framework for estimating dynamic panel-data models using difference-GMM estimators. Difference-GMM estimation starts by first differencing the model, and then adopting the lagged values of the dependent and explanatory variables in their levels as instruments in the firstdifferenced equations. Such estimation is based on two main assumptions. Firstly, the idiosyncratic error term $\left(\epsilon_{i, t}\right)$ is not serially correlated. Secondly, the explanatory variables are weakly exogenous (not strictly exogenous).

The specified model in equation (2) can be represented in its first-differenced form in the following way, while including INFST $_{i, t}$ in the control variables $\left(X_{i, t}\right)$ :

$\left(y_{i, t}-y_{i, t-1}\right)-\left(y_{i, t-1}-y_{i, t-2}\right)=\alpha\left(y_{i, t-1}-y_{i, t-2}\right)+$

$$
\beta\left(X_{i, t}-X_{i, t-1}\right)+\left(\varepsilon_{i, t}-\varepsilon_{i, t-1}\right)
$$


Furthermore, Arellano and Bond proposed two moment conditions or restrictions for difference-GMM estimation :

$$
\begin{aligned}
& E\left[y_{i, t-s}\left(\varepsilon_{i, t}-\varepsilon_{i, t-1}\right)\right]=0 \text { for } s \geq 2 ; t=3, \ldots, T \\
& E\left[X_{i, t-s}\left(\varepsilon_{i, t}-\varepsilon_{i, t-1}\right)\right]=0 \text { for } s \geq 2 ; t=3, \ldots, T
\end{aligned}
$$

These two moment conditions indicate that lagged dependent variable and other explanatory variables are exogenous in their levels, and hence, can be used as valid instruments in GMM estimation even if such variables are weakly exogenous.

However, Alonso-Borrego and Arellano (1996) and Blundell and Bond (1998) found that difference-GMM estimators have resulted in large finite sample bias and poor precision in simulation studies of dynamic panel-data models. Such case was apparent in models with moderately large autoregressive parameter and moderately small number of observations. In addition, they found that difference-GMM estimators become less informative if the value of $\alpha$ (coefficient of lagged dependent variable) increases towards unity and when the relative variance of fixed effects increases .

Meanwhile, Blundell and Bond (1998) argued that the abovementioned shortcomings of difference-GMM estimators might result in biased coefficients in short samples as shown by Monte Carlo simulations. Accordingly, Bond and Bover (1995) and Blundell and Bond (1998) proposed a system-GMM estimator in which lagged differences of variables are adopted as instruments for the equations in levels, while lagged levels of variables are adopted as instruments for the equations in first differences implying that instruments for differenced equations are similar to those of difference-GMM estimators.

Here, two additional moment conditions are required:

$$
\begin{aligned}
& E\left[\left(y_{i, t-s}-y_{i, t-s-s}\right)\left(\mu_{i}+\varepsilon_{i, t}\right)=0 \text { for } s=1\right. \\
& E\left[\left(X_{i, t-s}-X_{i, t-s-s}\right)\left(\mu_{i}+\varepsilon_{i, t}\right)=0 \text { for } s=1\right.
\end{aligned}
$$


These two additional moment conditions indicate that there is no correlation between the differences of explanatory variables and unobserved fixed effects, even though the levels of these variables might be correlated to unobserved fixed effects. This implies that differences of explanatory variables can be adopted as valid instruments in system-GMM estimation (Alimi, 2015). In this paper, the system-GMM estimators are used to investigate the impact of physical infrastructure development on economic growth to deal with heterogeneity resulting from the unobserved country-specific effects in panel-data models and endogeneity resulting from the reverse causality between physical infrastructure development and economic growth. The validity of the specified model is then tested using two specification tests, which are Arellano-Bond (A-B) test for second-order serial correlation and Sargan test of overidentifying restrictions.

\section{Results}

The regression results for the specified model are detailed in table (3), where the first column represents the results without an interaction term for MENA countries and the second column shows the results after including an interaction term for MENA countries .

The results in column (1) show that physical infrastructure development has contributed positively to economic growth during 2000-2016 for the whole sample of 30 countries. The infrastructure quantity index has a positive and significant coefficient, where $1 \%$ increase in infrastructure quantity will result in $0.034 \%$ increase in real GDP per capita growth. This result complies with the results of other empirical studies such as Calderón and Servén $(2004,2010)$, Chakamera and Alagidede (2016), and Yilmaz and Çetin (2017).

Meanwhile, the coefficients of most control variables had largely expected signs. In this regard, the results have shown an evidence of conditional convergence in real GDP per capita, 
since the lagged GDP per capita had a negative and statistically significant coefficient.

Trade openness has contributed positively to economic growth as it had a positive and statistically significant coefficient. The different channels through which trade can promote economic growth such as increased competition and efficiency, technology transfer, and economies of scale might explain this result. Furthermore, inflation had a negative and statistically significant coefficient as expected by the theory. This is because inflation usually results in distorted incentives for investors and hence, misallocation of resources.

The coefficients of other control variables had the expected signs, as the coefficients of education and institutional quality were positive, while the coefficients of financial development and government size were negative. Financial development has been claimed by several empirical studies to have a weak impact on economic growth, particularly in countries with less developed financial markets. However, such variables were statistically insignificant as shown in the regression results. The same regression was then repeated after interacting the infrastructure quantity index with a dummy for MENA countries and including such interaction term to the regression, so that to check whether the results will differ for MENA countries. The results in column (2) show that infrastructure quantity is still contributing positively to economic growth, where $1 \%$ increase in infrastructure quantity will result in $0.038 \%$ increase in real GDP per capita growth. 


\section{Table (3)}

\section{Physical Infrastructure and Economic Growth}

Dependent variable: Growth in Real GDP per capita

Estimation: System-GMM Estimation Sample: 30 countries, 2000-2016

\begin{tabular}{|c|c|c|}
\hline Variable & (1) & (2) \\
\hline Infrastructure Quantity (INFST) & \multicolumn{2}{|c|}{$0.034 * *$} \\
\hline & $(0.013)$ & $(0.014)$ \\
\hline INFST*MENA & ـ & $\begin{array}{r}-0.019 \\
(0.02)\end{array}$ \\
\hline Initial GDP per capita & $\begin{array}{l}-0.176 * * * \\
(0.038)\end{array}$ & $\begin{array}{l}-0.202 * * * \\
(0.041)\end{array}$ \\
\hline Education & $\begin{array}{l}0.048 \\
(0.08)\end{array}$ & $\begin{array}{l}0.105^{*} \\
(0.056)\end{array}$ \\
\hline Trade Openness & $\begin{array}{l}0.038 * * \\
(0.017)\end{array}$ & $\begin{array}{l}0.052 * * \\
(0.024)\end{array}$ \\
\hline Financial Development & $\begin{array}{l}-0.008 \\
(0.017)\end{array}$ & $\begin{array}{l}-0.007 \\
(0.018)\end{array}$ \\
\hline Inflation & $\begin{array}{l}-0.002 * * * \\
(0.001)\end{array}$ & $\begin{array}{l}-0.002 * * * \\
(0.001)\end{array}$ \\
\hline Government Size & $\begin{array}{l}-0.014 \\
(0.02)\end{array}$ & $\begin{array}{l}-0.008 \\
(0.024)\end{array}$ \\
\hline Institutional Quality & $\begin{array}{c}0.015 \\
(0.049)\end{array}$ & $\begin{array}{l}-0.015 \\
(0.057)\end{array}$ \\
\hline Observations & 420 & 420 \\
\hline Instruments & 30 & 30 \\
\hline $\begin{array}{l}\text { Specification tests (p-values) } \\
\text { A-B test for second-order serial correlation }{ }^{\mathrm{a}} \\
\text { Sargan test of over-identifying restrictions }{ }^{b}\end{array}$ & $\begin{array}{l}0.924 \\
0.271\end{array}$ & $\begin{array}{c}0.742 \\
0.326\end{array}$ \\
\hline $\begin{array}{l}\text { Numbers in parenthesis are robust standa } \\
{ }^{*} \mathrm{p}<0.1, * * \mathrm{p}<0.5 \text {, and } * * * \mathrm{p}<0.01 \text { indica } \\
1 \% \text { level respectively. } \\
\text { a Null hypothesis for test is that diff } \\
\text { correlated. } \\
{ }^{\mathrm{b}} \text { Null hypothesis for test is that instrume } \\
\text { Moreover, the results show little } \\
\text { for MENA countries, since the in } \\
\text { insignificant. In addition, even if }\end{array}$ & $\begin{array}{l}\text { errors. } \\
\text { significance } \\
\text { enced error } \\
\text { are uncorrel } \\
\text { vidence of } \\
\text { raction tern } \\
\text { e negative }\end{array}$ & $\begin{array}{l}10 \%, 5 \% \text {, and } \\
\text { not serially } \\
\text { therror term. } \\
\text { statistically } \\
\text { cient of the }\end{array}$ \\
\hline
\end{tabular}


interaction term was statistically significant, the contribution of physical infrastructure to economic growth would still be positive in MENA countries but with a lower contribution of $0.019 \%$ for each $1 \%$ increase in infrastructure quantity.

The results also show a little difference for the control variables except for education that is now positive and statistically significant, as well as institutional quality that is negative but statistically insignificant .

Furthermore, the results of the specification tests have proven the validity of the specified model before and after including the interaction term, as the null hypotheses of the A-B test for second-order serial correlation and Sargan test of overidentifying restrictions were not rejected in both cases.

\section{Conclusion and Policy Implications}

MENA region has a volatile economic growth record that is largely dependent on World oil prices and its fluctuations. In this regard, MENA has not been able to sustain the high economic growth rates achieved in the 1970s after the rise in oil prices, and has been suffering from a declining growth trend since the 1990s compared to developing regions like South Asia and Sub-Saharan Africa that witnessed a rising growth trend since then.

Thus, the MENA region needs a new development model that aims at diversifying the region's economic structure through giving a greater role for the private sector and opening the economy with increased manufactured exports. However, the success of this new model will require some essential factors, and well-developed infrastructure should be at the center of this development model.

In this regard, although MENA countries have achieved real progress in terms of physical infrastructure provision, they are still lagging behind North America, Europe and Central Asia, and East Asia and Pacific. Therefore, physical infrastructure provision might be a potential source for sustainable economic growth in the MENA region, given that infrastructure 
development contributes positively to economic growth in MENA region.

This paper utilized system-GMM estimators to investigate the contribution of infrastructure quantity to economic growth during 2000-2016 for 30 countries including nine MENA countries, while focusing on telecommunications and energy. The results show that infrastructure quantity has contributed positively to economic growth in all countries as well as in MENA countries, implying that investment in infrastructure development should be among the priorities of development policies in MENA countries.

In this Context, the major policy implication is that governments in MENA countries should focus on promoting investment in physical infrastructure, while giving more attention to the quality of institutions and governance which affect largely on the quality of infrastructure provision as well as the management and maintenance of such provided infrastructure.

Meanwhile, MENA governments should give a greater role for the private sector in physical infrastructure provision through public-private partnerships (PPPs), which in turn will increase the relative importance of the private sector in MENA countries while reducing the burden on their public budgets.

In this way, physical infrastructure development will help MENA countries adopt a new development model with a more diversified economic structure, greater role for the private sector, increased manufactured exports, and more job opportunities.

The directions for future research involve investigating the relationship between infrastructure development and economic growth in more MENA countries and infrastructure sectors, while taking into account the infrastructure quality. 


\section{References}

Abdi, H., \& Williams, L. J. (2010). Principal component analysis. Wiley Interdisciplinary Reviews: Computational Statistics, 2.

Abdullah, H., Habibullah, M. S., \& Baharumshah, A. Z. (2009). The effect of fiscal variables on economic growth in Asian economies: A dynamic panel data analysis. International Journal of Business and Management, 4(1), 56-69 .

Alimi, R. S. (2015). Financial deepening and economic growth: System GMM panel analysis with application to 7 SSA countries. Munich Personal RePEc Archive (MPRA), Paper No. 65789, 1-11.

Arellano, M., \& Bond, S. (1991). Some tests of specification for panel data: Monte Carlo evidence and an application to employment equations. The Review of Economic Studies, 58(2), 277-297.

Aschauer, D. A. (1989). Is public expenditure productive? Journal of Monetary Economics, 23(2), 177-200.

Baltagi, B., \& Pinnoi N. (1995). Public capital stock and state productivity growth: Further evidence from an error components model. Empirical Economics, 20(2), 351-359.

Barro, R. J. (1990). Government spending in a simple model of endogenous growth. Journal of Political Economy, 98(5, Part 2), S103-S125 .

Barro, R. J. (1991). Economic growth in a cross section of countries. The Quarterly Journal of Economics, 106(2), 407 .

Blundell, R., \& Bond, S. (1998). Initial conditions and moment restrictions in dynamic panel data models. Journal of Econometrics, 87(1), 115-143.

Calderón, C., \& Servén, L. (2004). The Effects of infrastructure development on growth and income distribution. Central Bank of Chile, Working Paper 270.

Calderón, C. A. and Servén, L. (2010). Infrastructure in Latin America. World Bank Policy Research Working Papers, 5317. 
Calderón, C., \& Servén, L. (2014). Infrastructure, growth, and inequality: An overview. World Bank Policy Research Working Papers, 7034.

Cashin, P. (1995). Government spending, taxes and economic growth. IMF Staff Paper, 42, 237-269.

Chakamera, C., \& Alagidede, P. (2018). The nexus between infrastructure (quantity and quality) and economic growth in Sub Saharan Africa. International Review of Applied Economics, 32(5), 641-672.

Devarajan, S., Swaroop, V., \& Zou, H. F. (1996). The composition of public expenditure and economic growth. Journal of Monetary Economics, 37(2), 313-344 .

Duncan, F. P. \& Denaux, Z. S. (2013). Determinants of economic success in the Middle East and North Africa. Global Journal of Business Research, The Institute for Business and Finance Research, 7(5), 25-34.

Wooldridge, J., M. (2013). Introductory econometrics: A modern approach. 4th Edition, South-Western Cengage Learning, Ohio.

Jorgenson, D. (1991). Fragile statistical foundations: The macroeconomics of public infrastructure investment. Paper presented at Infrastructure Needs and Policy Options for the 90’S, American Enterprise Institute, Washington, D.C.

Khadraoui, N., \& Smida, M. (2012). Financial development and economic growth: Static and dynamic panel data analysis. International Journal of Economics and Finance, 4(5), 94-104.

Kodongo, O., \& Ojah, K. (2016). Does infrastructure really explain economic growth in Sub-Saharan Africa? Review of Development Finance, 6(2), 105-125.

Manuel A., \& Bover, O. (1995). Another look at the instrumental variable estimation of error-components models. Journal of Econometrics, 68(1), 29-51.

Nabli, M. K. (2007). Long-term economic development challenges and prospects for the Arab countries. In M. K. Nabli (Ed.), Breaking the barriers to higher economic growth: Better 
governance and deeper reforms in the Middle East and North Africa (pp. 3-28). Washington D.C., The International Bank for Reconstruction and Development, The World Bank.

Nabli, M. K. \& Veganzones-Varoudakis, M. (2007). Reform complementarities and economic growth in the Middle East and North Africa. In M. K. Nabli (Ed.), Breaking the barriers to higher economic growth: Better governance and deeper reforms in the Middle East and North Africa (pp. 29-75). Washington D.C., The International Bank for Reconstruction and Development, The World Bank.

Sahoo, P., \& Dash, R. K. (2012). Economic growth in South Asia: Role of infrastructure. Journal of International Trade and Economic Development, 21(2), 217-252.

Sanchez-Robles, B. (1998). Infrastructure investment and growth: Some empirical evidence. Contemporary Economic Policy, 16(1), 98-108.

Straub, S., Vellutini, C., \& Warlters, M. (2008). Infrastructure and economic growth in East Asia. World Bank Policy Research Working Papers, 4589.

Todaro, M., P., and Smith, S., C. (2011). Economic Development, 11th Edition, Addison Wesley.

Um, P. N., Straub, S., \& Vellutini, C. (2009). Infrastructure and economic growth in the Middle East and North Africa. World Bank Policy Research Working Papers, 5105.

Yılmaz, D., \& Çetin, I. (2017). The impact of infrastructure on growth in developing countries: Dynamic panel data analysis. In R. Das (Ed.), Handbook of research on economic, financial, and industrial impacts on infrastructure development (pp. 40-68). Hershey, PA: IGI Global. 
investigating the relationship waleed mohamedyoussef publishing date 30/9/2020

\begin{tabular}{|l|c|c|c|c|c|}
\hline \multicolumn{1}{|c|}{ Region } & $\begin{array}{c}\mathbf{1 9 7} \\
\text { 0s }\end{array}$ & $\begin{array}{c}\mathbf{1 9 8} \\
\text { 0s }\end{array}$ & $\begin{array}{c}\mathbf{1 9 9} \\
\text { 0s }\end{array}$ & $\begin{array}{c}\mathbf{2 0 0 0 -} \\
\mathbf{0 9}\end{array}$ & $\begin{array}{c}\mathbf{2 0 1 0 -} \\
\mathbf{1 6}\end{array}$ \\
\hline Sub-Saharan Africa & 4.4 & 1.6 & 1.9 & 5.2 & 4.1 \\
\hline South Asia & 3 & 5.6 & 5.5 & 6 & 6.7 \\
\hline $\begin{array}{l}\text { Middle East and North } \\
\text { Africa }\end{array}$ & 8.5 & 0.1 & 4.5 & 4.3 & 3.6 \\
\hline $\begin{array}{l}\text { Latin America and } \\
\text { Caribbean }\end{array}$ & 6.1 & 2.1 & 2.7 & 3 & 2.4 \\
\hline East Asia and Pacific & 4.8 & 5 & 3.7 & 4.2 & 4.8 \\
\hline Europe and Central Asia & 3.4 & 2.4 & 1.5 & 2 & 1.7 \\
\hline North America & 3.3 & 3.1 & 3.1 & 1.9 & 2.1 \\
\hline
\end{tabular}

Appendix A

Table (A.1)

Average Real GDP Growth by Region (\%)

Source: World Bank, World Development Indicators

Table (A.2)

OPEC Crude Oil Price (U.S. \$ per barrel)

\begin{tabular}{|c|c|}
\hline Year & Price \\
\hline 1970 & 1.21 \\
\hline 1971 & 1.7 \\
\hline 1972 & 1.82 \\
\hline 1973 & 2.7 \\
\hline 1974 & 11. \\
\hline 1975 & 10.43 \\
\hline 1976 & 11.6 \\
\hline 1977 & 12.5 \\
\hline 1978 & 12.79 \\
\hline 1979 & 29.19 \\
\hline 1980 & 35.52 \\
\hline Year & Price \\
\hline 1981 & 34 \\
\hline
\end{tabular}

Scientific Journal for Economic\& Commerce 
investigating the relationship waleed mohamedyoussef publishing date 30/9/2020

\begin{tabular}{|c|c|}
\hline $\mathbf{1 9 8 2}$ & 32.38 \\
\hline $\mathbf{1 9 8 3}$ & 29.04 \\
\hline $\mathbf{1 9 8 4}$ & 28.2 \\
\hline $\mathbf{1 9 8 5}$ & 27.01 \\
\hline $\mathbf{1 9 8 6}$ & 13.53 \\
\hline $\mathbf{1 9 8 7}$ & 17.73 \\
\hline $\mathbf{1 9 8 8}$ & 14.24 \\
\hline $\mathbf{1 9 8 9}$ & 17.31 \\
\hline
\end{tabular}

Source: Organization for Petroleum Exporting Countries (OPEC) and International Energy Agency (IEA)

Table (A.3)

Oil Rents (\% of GDP)

\begin{tabular}{|l|c|c|c|c|c|}
\hline \multicolumn{1}{|c|}{ Region } & $\mathbf{1 9 7 0}$ & $\mathbf{1 9 8 0}$ & $\mathbf{1 9 9 0}$ & $\mathbf{2 0 0 0}$ & $\mathbf{2 0 1 0}$ \\
& $\mathbf{S}$ & $\mathbf{S}$ & $\mathbf{S}$ & $\mathbf{- 0 9}$ & $\mathbf{- 1 6}$ \\
\hline North America & 1.19 & 1.42 & 0.41 & 0.38 & 0.35 \\
\hline Europe and Central Asia & 0.08 & 0.42 & 0.39 & 0.92 & 1.17 \\
\hline East Asia and Pacific & 0.96 & 1.28 & 0.41 & 0.75 & 0.68 \\
\hline $\begin{array}{l}\text { Latin America and } \\
\text { Caribbean }\end{array}$ & 2.58 & 4.37 & 2.01 & 3.70 & 2.79 \\
\hline $\begin{array}{l}\text { Middle East and North } \\
\text { Africa }\end{array}$ & 32.0 & 21.75 & 16.98 & 24.8 & $\begin{array}{c}22.7 \\
6\end{array}$ \\
\hline South Asia & 6 & & & 2 & 0.77 \\
\hline Sub-Saharan Africa & 5.34 & 1.15 & 0.82 & 0.96 & 0.79 \\
\hline
\end{tabular}

Source: World Bank, World Development Indicators 
Table (A.4)

Access to Electricity (\% of population)

\begin{tabular}{|l|c|c|c|}
\hline \multicolumn{1}{|c|}{ Region } & $\mathbf{1 9 9 0 s}$ & $\mathbf{2 0 0 0 - 0 9}$ & $\mathbf{2 0 1 0 - 1 6}$ \\
\hline Sub-Saharan Africa & 20.3 & 29.3 & 37 \\
\hline South Asia & 48.4 & 64.3 & 79.5 \\
\hline Middle East and North Africa & 88.6 & 93.8 & 97.2 \\
\hline Latin America and Caribbean & 88.6 & 93.6 & 96.8 \\
\hline East Asia and Pacific & 86.7 & 92.8 & 96.3 \\
\hline Europe and Central Asia & 99.2 & 99.7 & 99.9 \\
\hline North America & 100 & 100 & 100 \\
\hline
\end{tabular}

Source: World Bank, World Development Indicators

Table (A.5)

Electric Power Consumption (kWh per capita)

\begin{tabular}{|l|c|c|c|}
\hline \multicolumn{1}{|c|}{ Region } & $\mathbf{1 9 9 0 s}$ & $\mathbf{2 0 0 0 - 0 9}$ & $\mathbf{2 0 1 0 - 1 4}$ \\
\hline Sub-Saharan Africa & 307.8 & 433.6 & 643.1 \\
\hline South Asia & 307.8 & 433.6 & 643.1 \\
\hline Middle East and North Africa & 1390.1 & 2107.2 & 2740.9 \\
\hline Latin America and Caribbean & 1332.9 & 1722.9 & 2075.7 \\
\hline East Asia and Pacific & 1341.6 & 2210.8 & 3399.3 \\
\hline Europe and Central Asia & 4784.7 & 5285.2 & 5474.1 \\
\hline North America & 12926.0 & 13748.3 & 13359.5 \\
\hline
\end{tabular}

Source: World Bank, World Development Indicators 
Table (A.6)

Fixed Telephone Subscriptions (per 100 people)

\begin{tabular}{|l|c|c|c|}
\hline \multicolumn{1}{|c|}{ Region } & $\mathbf{1 9 9 0 s}$ & $\mathbf{2 0 0 0 - 0 9}$ & $\mathbf{2 0 1 0 - 1 6}$ \\
\hline Sub-Saharan Africa & 1.1 & 1.5 & 1.2 \\
\hline South Asia & 1.2 & 3.2 & 2.3 \\
\hline Middle East and North Africa & 6.6 & 14.1 & 15.7 \\
\hline Latin America and Caribbean & 9.0 & 17.0 & 17.6 \\
\hline East Asia and Pacific & 8.1 & 20.6 & 19.3 \\
\hline Europe and Central Asia & 31.2 & 38.1 & 35.0 \\
\hline North America & 59.9 & 59.8 & 42.2 \\
\hline
\end{tabular}

Source: World Bank, World Development Indicators 


\section{Appendix B}

\begin{tabular}{|r|r|r|}
\hline \multicolumn{1}{|c|}{ Country } & Classification by World Bank & \multirow{2}{*}{ Region } \\
\hline Algeria & Upper Middle Income & \\
\hline Bahrain & High Income & \\
\hline Egypt & Lower Middle Income & \multirow{2}{*}{ Middle East and North } \\
Africa (MENA)
\end{tabular}


